\title{
Contributions of the Program Inovar-Auto to the Automotive Manufacturers in Brazil
}

\author{
Nivaldo Luiz Palmeri ${ }^{1}{ }^{2}$, Oduvaldo Vendrametto ${ }^{1}$, João Gilberto Mendes dos \\ Reis $^{1}$, and Rosangela Kronig ${ }^{3}$ \\ 1 Paulista University, São Paulo, Brazil \\ 2 Centro Universitário Fundação Santo André - FSA, Santo André, Brazil \\ nivaldoluiz@uol.com.br \\ 3 Faculdade de Tecnologia do Estado de São Paulo - FATEC, São Bernardo, Brazil
}

\begin{abstract}
The Brazilian government intents to stimulate and modernize the national automotive industry. The Inovar-Auto program propose to improve the international competitiveness of automobile auto parts industry and to reduce the importations. This paper aims to verify the influence of the Inovar-Auto program in competitiveness of Brazilian automotive industry. To this end, we carried out a search regarding the investments to the following years of the program, the participation of international enterprises as stakeholders of the national industry and its next goals. The results showed that the major investments came from international companies.
\end{abstract}

Keywords: Competitiveness - Automotive industry in Brazil · Developing countries - Globalization

\section{Introduction}

Since the 90s the Brazilian automotive sector has being part of an international transformation. The opened market for a free trade and economy growth made the Brazilian market more attractive to the transnational automotive companies. Thus, the manufactures initiated a remodeling process, including the relationship with the local suppliers, incorporating hierarchical strategies, global sourcing, follow sourcing and its variations [1,2]. However, in the last five years, a trade balance deficit and a decrease of the automotive parts produced in Brazil jeopardize the future of the national supply chain [3].

The Brazilian government, as an attempt to change this scenario, issued the Acts 12.715 and 7.819 that created the Program to Incentive Technological Innovation and Aggregate the National Automotive Supply Chain (Inovar-Auto) $[4,5]$. The program aims to support the technological development, innovation, environmental protection, energetic efficiency and quality of both vehicles and auto parts. The Inovar-Auto has been build by a working group with participation of the Brazilian government, automotive enterprises, universities, associations, working unions and consultants [6]. The working group aim to evaluate if 
the program is robust enough to promote the national technological development to include Brazil in the international scenario.

The present study aims to evaluate the contributions of the Inovar-Auto program to the national automotive competitiveness. Thus, we analyzed the current legislation regarding the program, the investments proposed by the automotive sector in Brazil, and the nationality of the companies working in Brazil as well as the targets and requirements proposed by the national government. However, the initial proposal for the program has changed, since the financial resources, i.e. the incentive of the Inovar-Auto Program, has been applied not to either technological development or its transference, but to support new manufacturer plants, capacitation and marketing.

\section{Methodology}

We conducted an exploratory study based on a literature review. The information about to the Inovar-Auto program was obtained from the current legislation regarding it. In addition data were also collected from: specific publications of ANFAVEA (National Association of Manufactures of Automotive Vehicles); MDIC (Ministry of Development, Industry and International Trade); MCTI (Ministry of Science, Technology and Innovation); journals and specialized websites regarding the automotive sector as Automotive Business, Exame and others.

In order to evidence the divergences from the initial proposal of the program we analyzed the current legislation that supports it. Seventeen different legal acts have amended the program since the initial issued Act 12.715 in 20.112, until the Decree 8.544 in 2015.

These amendments represent requirements and procedures to capacitation of suppliers, expenses of strategic inputs, traceability, habilitations of companies and other factors that evidence the constant evolution the Inovar-Auto. We obtained the proposed investments of the manufacturers by the statistical report that was published in the website Automotive Business - Special Reports: Investments of Manufacturers 2011-2020, updated in August 2014 where the exchange rate is US\$ $1=\mathrm{R} \$ 2,40$ e Euro $1=\mathrm{R} \$ 3,30$ [7].

The information about the majority control of the enterprises was collected either in the Exame magazine [8] or in the Internet. The main goals and the achieved targets are available in the MDIC website [9].

The present research provides information to analyze the proposed budged by the manufacturers in Brazil, the goals of the program and the expected results initially proposed. This dataset constitutes the base to the conclusion of the present study.

\section{Literature Review}

Brazil has one of the biggest markets for production and commercialization of vehicles. The national supply chain is vast and it includes basic inputs produc- 
tion, auto parts suppliers, the productive process and the distribution chain [3]. The country needs to improve the production, search and expand the commerce to new markets as well as to support the national market, and stimulate the competition, efficiency and increase the productivity in the automotive chain from the production to the commercialization [9].

The program Inovar-Auto stimulates the competitiveness, the search for efficiency systemic gains due to the productivity increase in the automotive supply chain, the stages of production as well as the technological and commerce network. It also encourages investments due to taxes reduction, consequently it increases the technological standards of the vehicles, parts, components, and vehicular safety. To the enterprises that fulfill the requirements in order to be licensed to the program may be applied an IPI reduction up to $30 \%$. Fifty-five enterprises have the license regarding the program, comprehending 23 manufacturers, 15 importers and 17 project investors [9], and it must be renewed annually. In 2015,25 enterprises applied to renew their licenses and were approved by the MDCI [9].

It is possible to correlate the stage of development level of the automotive sector and the economic development of a country. Countries with a developed automotive industry such as USA, Germany, Japan, South Korea, have competitive factors in common such as: majority part of the manufacturers and their main suppliers, knowledge and comprehension of developed technology, innovation, connections in the international market and success regarding the technological development [10]. On the other hand, in most of the developing countries as Mexico and Brazil, the industrial park depends on both foreign capital and technology. Some characteristics are familiar between these countries as geographical latitude, cultural aspects and dependence of international technology for the automotive segment. The foreign manufacturers working on developing countries are connected to their supplier, mostly working also on the country, for market reasons in order to maximize their profits [2]. The local suppliers represent the 2 nd or $3 r d$ level in the supply chain. Their products are limited to supply the local market and they are represented by small and medium companies that are focused on operation activities [1]. These national small companies do not have conditions to fulfill the formal requirements to attend the Inovar-Auto Program. They are still part of the peripheral supply chain, producing exclusively technological obsolete components that are still being in use in national vehicles.

\section{Evolution of the Program Inovar-Auto}

The program Inovar-Auto represents an alternative to develop technology in vehicles produced in Brazil. Its main focuses are: safety; fuel consumption reduction; technological development; supply chain capacitation. However, it is still necessary additional efforts [11]. Laws, decrees and acts represent the legislation Table $1[6,12]$.

The program is currently: renewing the licenses; studying the availability of applying the surplus credit to next term of the licenses; conducting follow up 
Table 1. Relevant legislation to Inovar-Auto

\begin{tabular}{|c|c|}
\hline Legislation & Relevant \\
\hline Law $\mathrm{n}^{\mathrm{o}} 12.715 / 2012$ & $\begin{array}{l}\text { It releases the program to incentive the technological in- } \\
\text { novation and aggregation of the automotive supply chain. }\end{array}$ \\
\hline Law $n^{\circ} 12.996 / 2014$ & It alters the Law $\mathrm{n}^{\circ} 12.715 / 2012$ \\
\hline \multicolumn{2}{|c|}{ Decree $\mathrm{n}^{\circ} 7.819 / 2012$ It regulates the Law $\mathrm{n}^{\mathrm{o}} 12.715 / 2012$. } \\
\hline \multicolumn{2}{|c|}{ Decree $\mathrm{n}^{\circ} 8.015 / 2013$ It alters the Decree $\mathrm{n}^{\circ} 7.819 / 2012$} \\
\hline \multicolumn{2}{|c|}{ Decree $\mathrm{n}^{\circ} 8.294 / 2014$ It alters the Decree $\mathrm{n}^{\circ} 7.819 / 2012$. } \\
\hline Act $106 / 2013$ & It postpones the special licenses up to May 31, 2013. \\
\hline Act 11: & es the complemen \\
\hline Act 280 & $3 / 2013$ \\
\hline Act $296 / 2013$ & It regulates the $\mathrm{p}$ \\
\hline Act $297 / 2013$ & $\begin{array}{l}\text { It establishes the complementary regulation to the Decree } \\
\mathrm{n}^{\circ} 7.819 / 2012 \text {. }\end{array}$ \\
\hline Act $772 / 2013$ & $\begin{array}{l}\text { It establishes the complementary regulation to the Decree } \\
\mathrm{n}^{\circ} 7.819 / 2012 \text {. }\end{array}$ \\
\hline Act $257 / 2014$ & $\begin{array}{l}\text { It establishes the complementary regulation to the Decree } \\
\mathrm{n}^{\circ} 7.819 / 2012 \text {. }\end{array}$ \\
\hline Act $290 / 2014$ & It alters the Act $113 / 2013$. \\
\hline Act $318 / 2014$ & It alters the Inter-Ministerial Act $\mathrm{n}^{\circ} 772$. \\
\hline Act $74 / 2015$ & $\begin{array}{l}\text { It establishes the complementary regulation to the Decree } \\
\mathrm{n}^{\circ} 7.819 / 2012 \text {. }\end{array}$ \\
\hline & It alters the Decree $\mathrm{n}^{\circ} 7.819$ \\
\hline
\end{tabular}

auditing in the licensed enterprises to the continuation of the program during its term end in 2017 [6].

\section{Planned Investments}

The vehicles manufacturers have announced investments of US $\$ 22.3$ billions in Brazil for the next years, where US $\$ 2.3$ billions comprehends new manufacturers not yet producing in Brazil as Audi, BMW, Jaguar Land Rover, Chery, Foton, JAC Motors e Sinotruk. The remaining amount of US\$ 20.0 billions investments are related to manufacturers already install in Brazil that plans to implement new assembly lines to increase their production capacity, modernization of facilities, production of engines and components, new vehicles projects, nationalization and development of new product and $R \& D$ and others. The planned investments and the period, as well as the majority participation of the enterprises. Only US $\$ 500$ millions out of US $\$ 22.3$ billions initially announced, representing $2 \%$, are originated from Brazilian companies, as follow: Agrale, Volare e MMC Automotores do Brasil (Table 2) [7]. 
Table 2. Investments of the automotive manufacturers working in Brazil (Source: [7])

\begin{tabular}{lccc}
\hline \multicolumn{1}{c}{ Manufacturers } & Majority Participation US $\$$ Billions & Period \\
\hline Agrale & Brazilian & 0.017 & $2014 / 2015$ \\
FCA - Fiat Chrysler & Italian & 4.167 & $2011 / 2014$ \\
Ford & American & 1.994 & $2011 / 2015$ \\
General Motors & American & 2.708 & $2014 / 2018$ \\
Honda & Japanese & 0.417 & $2013 / 2015$ \\
Iveco & Italian & 0.481 & $2012 / 2014$ \\
MAN & German & 0.417 & $2012 / 2016$ \\
Mercedes-Benz & German & 0.625 & $2014 / 2016$ \\
MMC Automotores do Brasil & Brazilian & 0.417 & $2011 / 2015$ \\
Nissan & Japanese & 1.083 & $2011 / 2014$ \\
PSA Peugeot Citroën & French & 1.542 & $2012 / 2015$ \\
Renault & French & 0.308 & $2014 / 2019$ \\
Scania & German & 0.417 & $2014 / 2024$ \\
Toyota & Japanese & 0.417 & $2012 / 2015$ \\
Volare & Brazilian & 0.015 & $2014 / 2015$ \\
Volkswagen & German & 4.167 & $2014 / 2018$ \\
Volvo & Sweden & 0.820 & $2013 / 2015$ \\
Audi & German & 0.183 & $2013 / 2015$ \\
BMW & German & 0.275 & $2012 / 2014$ \\
BYD (Build Your Dreams) & Chinese & 0.083 & $2014 / 2015$ \\
Chery & Chinese & 0.530 & $2012 / 2014$ \\
Foton Aumark do Brasil & Chinese & 0.142 & $2012 / 2016$ \\
JAC Motors & Chinese & 0.417 & $2011 / 2014$ \\
Jaguar Land Rover & English & 0.313 & $2013 / 2020$ \\
Metro-Shacman & Chinese & 0.167 & $2012 / 2014$ \\
Sinotruk & Chinese & 0.125 & $2014 / 2016$ \\
Yunlihong Motors do Brasil & Chinese & 0.075 & $2012 / 2015$ \\
\hline & & &
\end{tabular}

\section{Targets of the Program Inovar-Auto}

The program Inovar-Auto program provides that's the qualified companies could take advantages of taxes (IPI). On the other hand, assumed commitments under the current targets of the goals [13].

\subsection{New Investments}

Investments must be implemented to install new facilities and vehicle production plants or new projects to improve vehicle assembly lines already working in Brazil. The licensed enterprises must present their projects and after approval they must implement it. The enterprises may import similar vehicles to the ones that will be produced by the new facility during its construction and apply the IPI reduction, introducing the product to the market with similar conditions comparing to a future stage when the plant start the production locally. The enterprises must also present the information regarding the investment projects 
evolution. The legal acts issued after the initial proposal for the program have altered the targets of the program due to pressure of the selected enterprises, stripping the proposals of its original characteristics. Basically, it was influenced to become a public funding to finance private interests as tax relief. These resources are including in the companies budgets as investments. A diversity of scopes with no relevance to technological development were also aggregated in the program. In the following items are described the topics of the program if implemented it would enhance the national competitiveness for exportation, and it would also provide national research and development centers of expertize.

\subsection{Energy Efficiency}

Energy efficiency, for the present study, is understand as the autonomy of a vehicle in kilometer per liter units, or energy consumption represented in mega joules per kilometer $(\mathrm{MJ} / \mathrm{km})$ and these measures are made according to the methodology established by the legislation of the program. The licensed enterprises must reach the minimum target of $12.08 \%$ reduction according to the Federal Decree no $7819 / 2012$. The current results are evaluated in specific periods during the license (Nov/16 - Oct/17).

\subsection{Research and Development}

The investments may be applied to basic research, applied research, experimental developments and technical support services. The enterprises must invest a percentage of their revenue in $\mathrm{R} \& \mathrm{D}$, increasing from $0.15 \%$ in 2013 to $0.50 \%$ in 2017. This investment aims to improve technology and innovation of new products and processes in the country.

\subsection{Engineering and Basic Industrial Technology}

The enterprises licensed as manufacturer or importer may also invest their capital in engineering, basic industrial technology and suppliers' capacitation. These investments may be applied in engineering development, basic industrial technology, employees' capacitation, new products development, creation of new projects for laboratories and research, test tracks, development of machinery and suppliers' capacitation.

The minimum percentage of investments in engineering increases progressively from $0.50 \%$ in 2013 to $1.00 \%$ in 2017 of the revenue of the licensed enterprise.

This requirement aims to develop the technology and innovation of new products and productive processes. Complementary regulation to the program InovarAuto introduces concepts, orientations, models, requirements and methodologies to follow up the accordance of the enterprises to the requirements. 


\subsection{Manufacturing Stages}

The licensed manufacturer must fulfill the minimum manufacturing stages, direct or indirect, regarding infrastructure and engineering. The manufacturing stages that must be conducted are: upholstery, welding, anti corrosive treatment and painting, plastic modeling, manufacture, gearbox manufacture, steering system and suspensions assemblage, electrical system assemblage, brake system and axis assemblage, chassis production or assemblage, assemblage, final checking, compatible tests and self infrastructure of laboratories to develop product tests, and others. At least $80 \%$ of the vehicles must fulfill the manufacturing stages, promoting the development of the national industry regarding productive capacity, fomenting the development of new suppliers to the manufacturing stages. The minimum amount o manufacturing stages rises from 8 in 2013 to 10 in 2017.

\subsection{Labeling and Standard Vehicle}

One of the specific objectives of the program is to increase the participation in the Labeling and Standard Vehicle Program (PBEV) conducted by INMETRO that aim to provide information regarding energetic performance of products contributing to consumer's decision.

\subsection{Industry Sustainability}

The suppliers of strategic inputs and machinery must inform in the Inovar-Auto Program Monitoring System the products provided to the licensed enterprises, including values and other characteristics. This information will provide knowledge about the automotive supply chain allowing the governmental institutions implementing policies to support the sector. The strategic inputs are: raw material, parts and components used to manufacture and aggregate in the vehicles; machinery and aggregate parts; upholstery and injection machinery and their parts. This objective is divided in two different targets:

Target 1 - The minimum of 700 suppliers registered in the Inovar-Auto Program Monitoring System until March/2015. This target considers the automotive supply chain in general (basic inputs, auto parts, tires, painting, etc.) and enterprises that are associated to the National Industry Union of Components to Automotive Vehicles (Sindipeças). It represents $85 \%$ of total sales to the InovarAuto licensed enterprises. Target 2 - Accordance of $95 \%$ of the supplier inputs and machinery.

\section{Discussion and Conclusions}

The program Inovar-Auto is contributing to the sustainable development of the automotive industry in Brazil. It has stimulating new plants as well as the modernization of the ones already producing, production of more modern vehicles, energy efficiency increase, investments in R\&D and engineering, nationalization 
of industrial processes and more participation in the Labeling and Standard Vehicle Program (PEBV).

When comparing the Brazilian initiative to developed countries automotive industry it is possible to notice that these countries have the majority participation of the enterprises the mains suppliers. In Brazil, however, the industrial plants are exogenous and international dependent regarding both technology and investments.

The investments provided by the program Inovar-Auto are $98 \%$ from international majority participation, influencing the technology transfer to the automotive sector and limiting the sustainable development in Brazil. The technology is introduced and licensed and do not incorporate the learning process of the research and development, keeping the industries in a position of dependent buyer.

The program Inovar-Auto has financed international enterprises using public resources investing in their production. These resources should come from the enterprises as a plan to become more competitive maintaining their markets. The enterprises in a capitalism society must compete for profits and as a consequence assume the risks.

The innovation and implementation of the segments that bring technology and competitiveness to boost the national automotive industry is no longer contemplated in scope of program Inovar-Auto.

This research aimed to evaluate using indicator the progress of the InovarAuto Program. However, we identified several distortions between the initial proposal and the current program. Consequently, politics and enterprises are being investigated for frauds.

\section{References}

1. Costa, I., Queiroz, S.R.: Autopeças no Brasil: Mudanças e Competitividade na Década de Noventa. Revista de Administração pp. 27-37 (2000)

2. Furtado, J.: La Transformation des Conditions d'insertion des Économies á Industrialisation Tardive dans L'économie Mondiale: Un Examen des Facteurs Généraux Suivi de leur Particularisation dans Cinq Secteurs Industriels. Thése de doctorat, Université de Paris-Nord, France (1997)

3. ANFAVEA: http://www .anfavea.com.br/anuario.html

4. Brazil: Lei 12.715/2012, http://inovarauto.mdic.gov.br

5. Brazil: Decreto 7819/2012, http://www2.camara.leg.br

6. Garcia, C.L.C., Laignier, G.: Inovar-Auto na Prática. The World Bank, São Paulo (2015)

7. Automotive Bussiness: http://automotivebusiness.anankecdn.net.br

8. Exame: http://exame.abril.com.br/topicos/melhores-e-maiores-2015

9. MDCI: http://www.desenvolvimento.gov.br

10. Ruff, F.: The Advanced Role of Corporate Foresight in Innovation and Strategic Management. Technological Forecasting \& Social Change pp. 37-48 (2014)

11. SIMEIA: http://www.simea.org.br/2015/pt/um-balanco-do-inovar-auto

12. MDCI: http://www.simea.org.br/2015/pt/um-balanco-do-inovar-auto

13. ABDI: http://inovarauto.mdic.gov.br 